\title{
Comparative Studies of Burning Rates and Water Boiling Time of Wood Charcoal and Briquettes Produced from Carbonized Martynia annua woody Shells
}

\author{
${ }^{1}$ L.G. Hassan, ${ }^{2}$ N.A. Sani, ${ }^{1}$ A.M Sokoto and *3U.G. Tukur \\ 1 Department of Pure and Applied Chemistry Usmanu Danfodiyo University, Sokoto \\ 2Department of Chemistry, Federal University Gusau \\ ${ }^{3}$ Sokoto Energy Research Centre Usmanu Danfodiyo University, Sokoto \\ [Corresponding Author: Email: tukurgwadangaji@gmail.com]
}

\section{ABSTRACT}

This study was conducted to compare the combustion properties of briquettes produced from carbonized Martynia annua woody shells and wood charcoal. Two different briquette samples were produced: Sample (A), is made up of carbonized shells powder plus starch as binding agent while Sample (B), consists of carbonized shells plus waste paper as binding agent. The parameters investigated include calorific value, ignition time, burning rate, and specific fuel consumption. Water boiling time and time taking by the Samples to burn to ashes were also determined. Water boiling time of the briquettes Sample A competed favorably with wood charcoal. Sample B has the lowest calorific value $(5479.31 \pm 4.14 \mathrm{cal} / \mathrm{g})$, wood charcoal $(6815.12 \pm 0.53 \mathrm{cal} / \mathrm{g})$ was the highest, followed closely by fuel briquettes Sample A $(6811.18 \pm 4.33 \mathrm{cal} / \mathrm{g})$. The calorific values of Sample $A$ and wood charcoal were not significantly different $(P>0.05)$. The burning rate of the fuel briquettes and wood charcoal ranged from $3.16 \pm 0.06 \mathrm{~g} / \mathrm{min}$ in Sample A to $3.03 \pm 0.05$ $\mathrm{g} / \mathrm{min}$. The time taken by Sample A and wood charcoal to burn to ashes were $95.0 \pm 2.5 \mathrm{~min}$. and $99.2 \pm$ 4.2 minutes respectively. Briquettes sample $B$ took $73.5 \pm 3.2 \mathrm{~min}$ to completely burn to ashes. The values for the water boiling time and specific fuel consumption for Sample $A$ and wood charcoal were also not significantly different $(P>0.05)$. Sample $B$ has the shortest ignition time and highest burning rate compare to Sample A and wood charcoal. The results confirmed that, the fuel briquettes from carbonized Martynia annua woody shells can serve as supplement or alternative energy sources to wood charcoal for domestic cooking and heating.

Key words: Biomass, Martynia annua, Woody shells, Carbonization, Briquettes

\section{INTRODUCTION}

Biomass is believed to be an important renewable energy source that could enhance environmental sustainability (Grover and Mishra, 1996). Forest biomass in the form of firewood and charcoal are predominant sources of energy for cooking and heating especially in the developing nations (Bamiro and Ogunjobi, 2015). Inefficient utilization of these forest biomass resources as firewood and charcoal has resulted into massive deforestation and other environmental problems (Ojekunle, 2014). In Nigerian context, statistics have shown that over 50 million metric tons of fuel wood is consumed annually and $60 \%$ of the consumers are living in the rural areas (Davies and Abolude, 2013). To overcome these problems, briquetting technology is the prime alternative. Briquetting is the process of converting loose combustible material into uniformly shaped blocks of compressed fuel that can be utilized conveniently, transported easily and stored safely for future uses. Conversion of loose organic wastes to briquettes is an attempt to provide alternative energy source and to avoid adverse environmental degradation related to the use of conventional fuels (William and Mary, 2006).

Attention from the scientific community on biomass briquetting technology is gaining tremendous attention essentially to bridge the gap between fuel supply and demand as well as to safeguard the environment from consequences associated with fossil fuel combustion. Briquetting 
technology makes use of biomass residues that could otherwise go to waste. A fuel briquette improves biomass handling characteristics, increases the volumetric calorific values, and reduces transportation, collection, and storage costs (Grover and Mishra, 1996). Biomass briquettes may be used directly as solid fuel for cooking and heating or converted via a variety of technologies (Pyrolysis, Gasification) into liquid or gaseous forms for electricity generation. Briquettes are widely utilized by distilleries, bakeries, and restaurants, (Grover and Mishra, 1996). Different biomass materials can be turned into clean burning fuel briquettes for direct burning or gasification. For instance, materials such as groundnut shells (Oyelaran et al. 2015) palm kernel (Ugwu and Agbo, 2010). Others like, millet straws, wheat straws, sorghum stalks, | maize stalks, corn cobs (Karunanithy et al. 2012), coconuts shells, rice husks (Oladeji, 2010), cotton wastes, sugarcane bagasse, water hyacinth (Davies and Abolude, 2013) plastic waste from dumpsites (Chart et al., 2010) and carbonized agric waste (Zubairu and Gana, 2014) are also used as energy sources.

Martynia annua is commonly known as cat's claw or devil's claw, a bushy annual herb $2-3 \mathrm{~m}$ height. Mostly $6-15 \mathrm{~cm}$ wide, the leaves are broad, round and along with tubular flowers (Flora et al. 2013), the seed pods are green and fleshy at first, and drying to a black woody capsule usually it grows I as a weed of agricultural, forest and savannah land, waste paper consist of $25-40 \%$ of municipal waste generated each year globally (Oyelaran et. al., 2015) which can transform into fuel briquettes. Briquetting technology is an opportunity in confronting both waste disposal and domestic fuel challenge. The aim of this study is to compare the burning rates and water boiling time of wood charcoal and briquettes produced from carbonized Martynia annua woody shells.

\section{MATERIALS and METHODS \\ Sample collection}

Martynia annua woody shells were collected from a plantation behind convocation ground, Usmanu Danfodiyo University, Sokoto (UDUS). Waste paper used as binding agent for Sample B was collected from dumb site, UDUS. Starch used as binding agent for Sample A was purchased from Sokoto Central Market.

\section{Carbonization}

Martynia annua woody shells were carbonized in a simple drum kiln method (Adam, 2009). The waste paper was shredded and immersed in water for two days before blending with charred powder. The starch was prepared according to the method reported by Praveena et al. (2014).

\section{Briquettes Production}

The carbonized materials collected from carbonization chamber was pulverized manually using mortar and pestle and then sieved using a 200 micron sieve. The prepared charcoal powder was mixed with starch as a binder at 85:15 ratio for Sample (A), and charcoal powder plus fermented waste paper at 80:20 ratio for Sample (B) before compaction. Two different samples were produced, i.e. Sample (A), carbonized shells powder plus starch as binding agent and Sample (B), carbonized shells plus waste paper as binding agent. The produced briquettes were dried for two weeks to reduce moisture contents using solar dryer.

\section{Water Boiling Test}

Water Boiling Tests was conducted by combusting $350 \mathrm{~g}$ of briquettes and wood charcoal samples, respectively using charcoal stove to compare the fuel combustibility and the fuel that cooked food faster. One liter of water was used for the test. The temperature reading was taken after every minute with mercury in glass thermometer (Onuegbu et al., 2011) until the water started to boil. The time taken by each sample to burn to ashes was monitored using stop watch. Specific fuel consumption during 
water boiling test was calculated using equation

(1):

$$
\text { Specific fuel consumption }=\frac{\text { mass of fuel consumed }(\mathrm{kg})}{\text { total mass of boiling water (litre) }}
$$

\section{Ignition Time Determination}

Ignition time was determined as reported by Oladeji (2010). The samples was graduated in centimeters, ignited at the bottom and allowed to burn until it extinguished itself. The rate at which flame propagated was calculated by dividing the distance burnt by the time taken in seconds as shown in equation (2):

$$
\text { Ignition time }=\frac{\text { distance burnt }(\mathrm{mm})}{\text { total total time taken }(\mathrm{sec})}
$$

\section{Burning Rates Determination}

Briquettes burning rate were determined by recording the briquettes weight before combustion and after the briquettes were completely burnt, the rate at which fire consume the briquette samples were calculated using equation (3) (Onuegbu et al., 2011).

$$
\begin{aligned}
& \text { Burning rate } \\
& =\frac{\text { mass of total fuel consumed }(\mathrm{g})}{\text { total total time taken }(\mathrm{min})}
\end{aligned}
$$

The calorific value of the briquettes and wood charcoal samples was determined using oxygen bomb calorimeter, according to the method adopted from Vongsaysana and Achara (2009),

\section{RESULTS and DISCUSSION}

Table: 1: Briquette parameters

\begin{tabular}{lllll}
\hline Samples & Shape & Diameter $(\mathbf{c m})$ & Height $(\mathbf{c m})$ & Weight $\mathbf{( g )}$ \\
\hline Sample A & cylindrical & 2.9 & 3.9 & 275 \\
Sample B & cylindrical & 3.5 & 3.9 & 225 \\
\hline
\end{tabular}

Table: 2: Comparative Combustion Characteristics of Briquettes with Wood Charcoal

\begin{tabular}{llll}
\hline Fuel characteristics & Sample A. & Sample B. & $\begin{array}{l}\text { Wood } \\
\text { charcoal }\end{array}$ \\
\hline Calorific value (cal/gram) & $6811.18 \pm 4.33$ & $5479.31 \pm 4.14$ & $6815.12 \pm 0.53$ \\
Ignition time(mm/s) & $1.11 \pm 0.03$ & $1.98 \pm 0.01$ & $0.91 \pm 0.07$ \\
Water boiling time (min.) & $12.41 \pm 0.55$ & $15.30 \pm 1.55$ & $11.50 \pm 2.11$ \\
Burning rate (g/min.) & $3.68 \pm 0.06$ & $4.76 \pm 0.15$ & $3.53 \pm 0.05$ \\
Specific fuel consumption (g/l) & $231.0 \pm 1.31$ & $268.0 \pm 1.44$ & $221.0 \pm 1.31$ \\
Time taken to burn to Ashes (min.) & $95.0 \pm 2.5$ & $73.5 \pm 3.2$ & $99.2 \pm 4.2$ \\
\end{tabular}

Notes: Plus or minus values stands for standard deviation of triplicate test result

The result of comparative analysis of physical parameters and combustion characteristics of briquette and wood charcoal samples are presented in Table 1 and 2 and represented 
using charts as shown in Figure1 to 4. Sample (A) has the highest calorific value compared to (B) while Sample (B) has highest ignition time, water boiling time and specific fuel consumption. Calorific value is a major quality index for briquette fuels. Table 2 indicates that Sample (A) has the highest calorific value $6811.18 \pm 4.33$ cal/g compared to Samples B, $(5479.31 \pm 4.14$ $\mathrm{cal} / \mathrm{g}$ ), while there is no significant difference between the calorific values of briquettes sample $A$ and wood charcoal. From the literatures, wood charcoal calorific value ranges from $<6894 \mathrm{cal} / \mathrm{g}$ to $>8345 \mathrm{cal} / \mathrm{g}$, depending on the tree species. Gebresas et al. (2015) studied charcoal briquettes obtained from carbonized sesame stalk using $15 \%$ clay as binder the calorific value found to be $4647.75 \mathrm{cal} / \mathrm{g}$. Therefore charcoal briquettes offer greater energy per unit weight than raw biomass.

The result for ignition time (Table 2) showed that briquette Sample B increases by blending char with waste paper as binding agent. This can be explained from the fact that waste paper contains more volatile matter; therefore, using waste paper as binding agent in the briquette will definitely increase the ignitibility of the briquette. The ignition time was the average time taken to achieve a steady glowing flame. The results of ignition time as shown in Table 2 showed that sample $B$ ignites at $1.98 \pm 0.01 \mathrm{~mm} / \mathrm{s}$ which is faster than $1.11 \pm 0.03 \mathrm{~mm} / \mathrm{s}$ for sample $A$ and $0.91 \pm 0.07 \mathrm{~mm} / \mathrm{s}$ for wood charcoal, respectively. Therefore blending waste paper with charcoal powder increases the ignitibility of the briquette.
Low density, high volatiles matter content in briquettes could highly be responsible for the fast combustion (Onuegbu et al. 2011). Briquette with a favorable ignition has better thermal efficiency with less environmental hazards (Praveena et al. (2014).

Water boiling test result from Table 2 showed that sample $B$ takes longest time to boil 1 liter of water $(15.30 \pm 1.55 \mathrm{~min}$.$) compared to sample A$ $(12.41 \pm 0.55$ min.) and wood charcoal (11.50 \pm 2.11$)$. Charcoal briquettes are a substitute for wood charcoal because of their similar combustion characteristics such as low volatiles content, higher fixed carbon content (Vongsaysana and Achara 2009).

The burning rate of the briquette samples (Table 2) showed that briquettes Sample $A$ has the slowest burning rate $(3.68 \pm 0.06 \mathrm{~g} / \mathrm{min}$.) compared to Sample B $(4.76 \pm 0.15 \mathrm{~g} / \mathrm{min}$.). This is associated with addition of waste paper to sample B; carbonized materials blended with waste paper can improve the thermal conductivity of the fuel ignition time and burning rate due to higher volatile matter content. Therefore Sample A has lower volatile matter than Sample B. in comparison to wood charcoal $(3.53 \pm 0.05 \mathrm{~g} / \mathrm{min})$ a statistical tool showed the burning rate for Sample A and wood charcoal are not significantly different $(P>0.05)$. Airflow grooves on the stove, smaller briquettes size influences the drying time, burning rate, and how often the user must feed the stove during cooking.

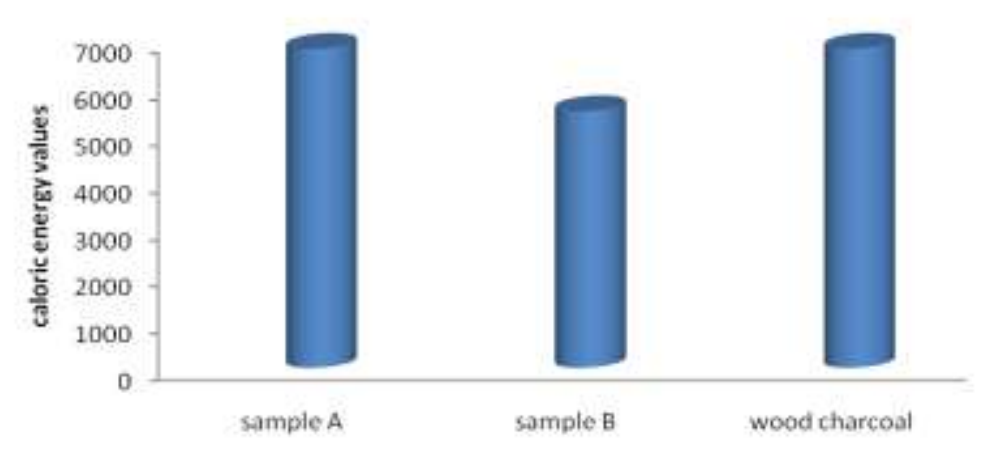

Figure 1: Calorific Value (cal/g) 


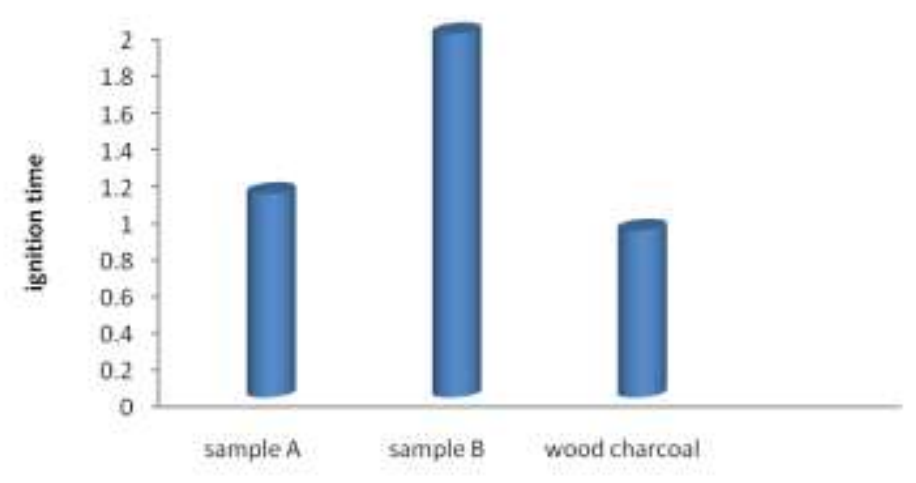

Figure 2: Ignition Time $(\mathrm{mm} / \mathrm{s})$

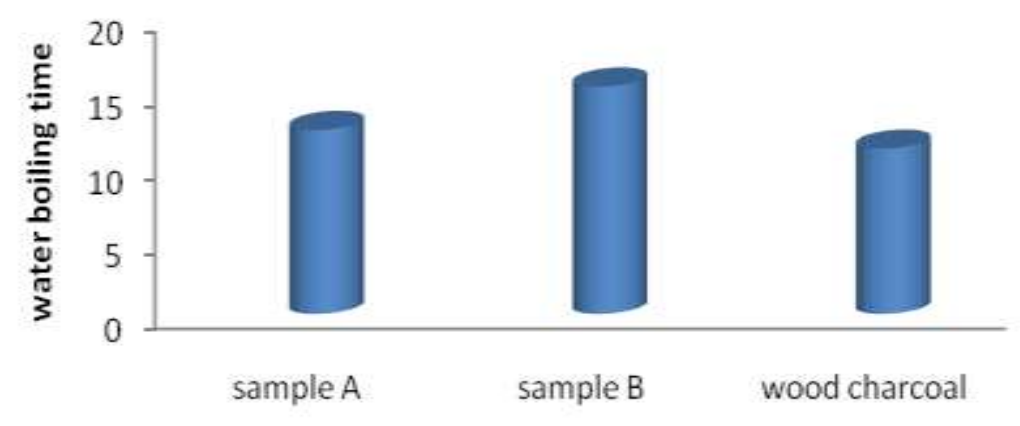

Figure: 3. Water Boiling Time

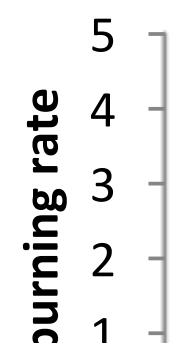

Figure 4. Burning rates $(\mathrm{g} / \mathrm{min})$

Wood charcoal took $99.2 \pm 4.2$ min. to burn to ashes a little bit longer than sample $A$. which took $95.0 \pm 2.5$ min. But sample B takes only $73.5 \pm 3.2$ min. to burn completely into ashes. Table 2 showed that carbonized shells char-powder can be compacted with assistance of binding agent to replace wood charcoal. Increasing the amount of binder increases the briquettes density, durability, time taken to burn to ashes and shear strength of the briquettes (Xianglan etal., 2001). Biomass Briquettes gives the best fuel, in terms of calorific value, ignition time, time to boil one liter of water 
and time taken to burn completely to ash are comparable to wood charcoal. Briquettes from plastic waste can be used in small scale gasification system (Chart et al. 2010).

\section{CONCLUSION}

Briquettes from carbonized Martynia annua woody shells, Sample (A) char-dust plus starch as binder under goes combustion test and found to have combustion characteristics comparable to that of wood charcoal, in terms of calorific value (Figure 1), burning rates (Figure 4) and specific fuel consumption during water boiling test (Figure 3). To consider the significance of waste paper blends, for Sample B, the ignition ability (Figure 2 ), burning rate increased with waste paper blends, conversely energy value per gram decreased (Sample B). Briquette containing charpowder and waste paper are more durable in terms of handling but with less heating value. There is huge opportunity here in confronting both the waste problem and the domestic fuel challenge at the same time. Fuel briquettes, which can be made from different types of waste material, offer a low-cost alternative domestic fuel to low-income families for their daily meals. Briquettes which are environmentally friendly can be locally produced in both rural and urban areas even with very little incomes.

\section{REFERENCES}

Adam, J. C. (2009). Improved and More Environmentally Friendly Charcoal Production System Using a Low-Cost Retort-Kiln (Eco-Charcoal). Journal of Renewable Energy.34:1923 - 1925

American Society for Testing Materials (ASTM) (1990) Annual Book of ASTM Standards, Part 26: Gaseous Fuels, Coal and Coke; Atmospheric Analysis, D492: 243 - 249

Bamiro, O. M., and Ogunjobi, J. O. (2015). Determinants of Household Energy Consumption in Nigeria: Evidence from Ogun State. Research Journal of Social Science and Management. 4(12):35-41

Chart, C., Boonya, C. and Chettiyappan, V. (2010). Recovery of Plastic Wastes from
Dumpsite Refuse-Derived Fuel and its Utilization in Small Gasification system. Journal of Bioreources Technology. 101: 1522-1527.

Davies, R.M and Abolude, D.S. (2013). Ignition and Burning Rate of Water Hyacinth Briquettes. Journal of Scientific Research and Reports. 2 (1):111 -120

Flora, G., Josephine, M. M., Chandra, M., Nanthini, M., Shalini, K., Shantha, P., Ranjni, A. S., and Valli, S. (2013). Study on Antioxidant Potential of Different Parts of Martynia annua Linn-A Road Side Weed. International Journal of Development Research. 3(9): pp. 51-54.

Grover, P. D. and Mishra, S. K. (1996). Biomass Briquetting: Technology and Practices; Field Document no. 46, Food and Agricultural Organization of the United Nations, Bangkok, 1996.

Karunanithy, C., Wang, V., Muthukumarappan, K., and Pugalendhi, S. (2012). Physiochemical Characterization of Briquettes Made From Different Feed Stocks. Biotechnology Research International. pp 7-12.

Oladeji, J.T. (2010) Fuel Characterization of Briquettes Produce from Corncob and Rice Husk Residue. The Scientific Journal of Science and Technology. 2 (1): $101-106$

Onuegbu, T.U., Ekpunobi, U.E., Ogbu, I.M., Ekeoma, M.O. and Obumselu, F.O. (2011). Comparative Studies of Ignition Time and Water boiling Test of Coal and Biomass Briquettes Blend. IJRRAS, 7 (2): 153-159

Okhakhu, P.A (2016). Climatic Implications of Environmental Development in Nigeria. Development Country Studies. 6(1):5059

Oyelaran O. A. Bolaji B. O. Waheed M. A. and Adekunle M. F. (2015). An Experimental Study of Combustion Characteristics of Groundnut Shells and Waste Paper Admixture Briquettes. KKU Energy Journey; 42(4): 283-286 
Ojekunle, O. Z. (2014). The Effects and Linkages of Deforestation and Temperature on Climate Change in Nigeria. Global Journal of Sciences Frontier Research: $\mathrm{H}$, Environment and Earth Sciences.14 (6): 9-18.

Praveena, U., Raju, A.I., Satya, M., Ramya, J. K., Rao, S.S. (2014). Studies on Development of Fuel Briquettes Using Biodegradable Wastes Materials. Journal of Bioprocessing and Chemical Engineering. 2(1): $2348-3768$.

Teixeira, S. R., Pena, A.F.V and Miguel, A.G. (2010). Briquetting of Charcoal from Sugar-Cane Bagasse Fly Ash (SCBFA) as an Alternative Fuel. Journal of Waste Management.30:804-807.

Vongsaysana, S., Achara U., (2009). Comparison of the Physical and Chemical Properties Briquette and Wood Charcoal in Khammouane Province, Lao PDR.
Journal of Environment and Natural Resources, 7(1): 12-22

William, P. C. and Mary, A. C., (2006). Principle of Environmental Science, Iniquity and Applications. $3^{\text {rd }}$ edition. pp. 296-298

Xianglan, Z., Deping, X., Zhihua, X., Zhihua, X., Qingru C., (2001). The Effect of Different Treatment Conditions on Biomass Binder Preparation for Lignite Briquette. Journal of Fuel Processing Technology, 73: 185196.

Ugwu K.E and Agbo K.E., (2010). Briquetting of Palm Kernel Shell. Federal University of Technology Owerri, (FUTO) Alternative Energy International Conference 2010. Owerri, Nigeria.

Zubairu, A. and Gana S, A. (2014). Production and Characterization of Briquette Charcoal by Carbonization of AgroWaste. Journal of Energy and Power. 4(2): 41-47 